\title{
The effect of flexible work arrangements on ethical decision-making
}

\author{
Pradita Sita Devi Normasari, ${ }^{1}$ Bertina Sjabadhyni ${ }^{1 *}$ \\ ${ }^{1}$ Faculty of Psychology, Universitas Indonesia, Depok - Indonesia
}

\begin{abstract}
This study aimed to compare the impact of different types of flexible work arrangements (flextime and telecommuting) on ethical decision-making. Ethical decision-making is when individuals use their moral basis to determine what is right and wrong in a given situation. It involves an awareness of moral dilemmas and consideration of the consequences of decisions. Flexible work arrangements are offered to promote individuals' ethical decision-making by balancing their needs at work and outside work, such as spending time with family. This research was conducted on 185 employees and used a quantitative approach that utilizes experimental methods with a post-test-only design. Employees' ethical decisionmaking was measured using two vignettes. Data analysis was conducted using the independent sample t-test parametric statistical technique. The study results indicated a $t=4.21$ and a significance level of $.00(\mathrm{p}<.05)$, which showed that this study's working hypothesis was acceptable. It concluded that there were differences in ethical decision-making between two types of flexible work arrangements: flextime and telecommuting groups.
\end{abstract}

Keywords: flexible work arrangements; ethical decision-making

Abstrak: Penelitian ini bertujuan untuk menyelidiki perbedaan jenis pengaturan kerja yang fleksibel pada pengambilan keputusan etis dengan membandingkan waktu kerja fleksibel dan telekomunikasi. Pengambilan keputusan etis adalah proses individu menggunakan dasar moral mereka untuk menentukan apa yang benar dan salah dalam situasi tertentu. Ini melibatkan kesadaran akan dilema moral dan pertimbangan konsekuensi dari keputusan. Pengaturan kerja fleksibel ditawarkan sebagai cara untuk meningkatkan pengambilan keputusan etis individu dengan memungkinkan mereka untuk menyeimbangkan kebutuhan mereka di tempat kerja dan di luar pekerjaan, seperti menghabiskan waktu bersama keluarga. Penelitian ini dilakukan pada 185 karyawan dan menggunakan pendekatan kuantitatif yang menggunakan metode eksperimental dengan desain post-test-only. Pengambilan keputusan etis karyawan diukur dengan menggunakan dua vignettes. Analisis data dilakukan dengan menggunakan teknik statistik parametrik independent sample t-test. Hasil penelitian menunjukkan nilai $\mathrm{t}=4.21$ dan tingkat signifikansi $0,00(\mathrm{p}<0,05)$, yang menunjukkan bahwa hipotesis kerja penelitian ini dapat diterima. Dapat disimpulkan bahwa terdapat perbedaan pengaturan kerja fleksibel pada pengambilan keputusan etis antara kelompok flextime dan telecommuting.

Kata Kunci: pengaturan kerja fleksibel; pengambilan keputusan etis

\footnotetext{
*Corresponding Author: Bertina Sjabadhyni (e-mail: berti@ui.ac.id), Faculty of Psychology, Universitas Indonesia, Jl. Kampus Baru Depok 16424-Indonesia.
} 


\section{Introduction}

Issues concerning ethics, moral development, and ethical decisions in organizational contexts have been studied extensively. In organizations, ethical principles and professional rules may direct employees to act in certain ways when overcoming moral problems. Employees are likely also to use their moral standards to make decisions, either ethical or unethical. Today, employees need to be flexible when facing dilemma situations that require quick decisionmaking, and they must be able to consider the consequences of their decisions Uones, 1991; Lincoln \& Holmes, 2010). These traits can prevent employees from making decisions that could harm the organization (Bazerman \& Sezer, 2016).

It is important to consider moral aspects when trying to understand ethics and decisionmaking processes because when individuals face dilemma situations, their decisions have moral and legal consequences (Lincoln \& Holmes, 2010). For example, suppose an employee is meant to have finished a certain work task by a certain day, but he or she has not done so yet. The employee then has two choices: either to skip work and say they are sick or to confess that they have not completed the task. This dilemma situation involves a process of moral judgment, and the employee's final choice may depend on the values he or she holds or normally follows. In some cases, employees may make unethical choices and act dishonestly, directly or indirectly, harming the organization. Therefore, understanding ethical decision-making is in the organization's interests.

Ethical decision-making at an individual level is a process whereby an individual uses their moral basis to make an ethical decision that is legal, acceptable and accepted by the community (Carlson et al., 2009; Jones, 1991). An individual has several choices, and the most ethical choices are ethical decisions (Sparks \& Pan, 2010). In organizations, ethical behavior is considered an important criterion for individual decisionmaking (Trevino \& Youngblood, 1990). Ethical decision-making involves an ethical reasoning process that elaborates individuals' moral awareness and cognitive abilities which turns into action to implement the decisions that have been taken (Wisesa, 2011).

In organizations, moral considerations sometimes arise that do not impinge on existing choices and merely support decision-making. Individuals in an organization focus on the surrounding environment to consider the effects of their decisions, which may be measured through, for example, the existence of a reward system and applicable rules that influence individuals in ethical decision-making (Jones, 1991; Trevino, 1986). Moral problems are present in individual actions that are performed freely, and these actions can harm or benefit others (Jones, 1991). If choices are considered good or bad based on an individual's morals, this can positively or negatively affect (Carlson et al., 2009).

The decision-making process consists of four stages (Lincoln \& Holmes, 2010; Musbah et al., 2016; Rest \& Barnett, 1986). First, ethical recognition or moral awareness that can interpret a situation as either ethical or not. Second, ethical assessment or moral judgment that can determine an ethically right action. Third, ethical intention or moral motivation that ethically prioritizes alternatives. Finally, ethical behavior or moral actions that involve ethically driven 
behavior. Moral awareness is an acknowledgment that a situation involves a moral dilemma. Moral judgment involves the development and consideration of choices and a reflection on their consequences. Moral intention refers to the intent to choose moral decisions over other choices that represent different values. The final stage in the decision-making process, in which an individual must decide, is a moral action (Rest \& Barnett, 1986). For ethical decisions to emerge, this process requires an awareness of moral dilemmas, consideration of the consequences of decisions, and morally appropriate decisionmaking (Lincoln \& Holmes, 2010).

Ethical decision-making processes also change with increasing job demands, with employees seeking to achieve a better balance between work and non-work activities (Lincoln \& Holmes, 2010). Ethical decision-making in the organizational context has been studied previously, but changes in the modern workforce mean that employees face various new ethical dilemmas. Work is an essential element of a person's life. Individuals decide to accept a job, how long to remain in a job, and quite a job. The increasing numbers of working partners, single parents, and individuals caring for relatives and others have necessitated changes to the amount of time and energy allocated to work and family activities (Sok et al., 2014). Increasing work demands are also contributing to change for employees. Flexible work arrangements are offered as a solution to individuals' ethical decision-making processes regarding balancing work and outside-of-work needs, such as spending time with family (Pedersen \& Lewis, 2012). These arrangements can reduce an employee's sense of a conflict between their work role and their life outside work (Radcliffe \& Cassell, 2014).
Rau and Hyland (2002) defined a flexible work arrangement as a work option that allows flexibility when completing telecommuting (remote work) and/or when completing work tasks (flextime). Flexible work arrangements can assist employees to manage their time and work effectively. Flexible work arrangements can help individuals manage organizational changes by offering increased flexibility in work relationships and arranging work schedules (Spreitzer et al., 2017). Traditionally, individuals have left work to go home at the close of the organization's business hours; that is, employees' presence has been required at an office. By applying flexible work arrangements, individuals can, for example, set their schedules so that they leave work early and thus arrive home early, or complete work tasks without being present in the office (Rau \& Hyland, 2002; Ryan \& Wessel, 2015). Employees with flexible work schedules can manage their lives better because they can be flexible in when and how their hours of work are completed (Rau \& Hyland, 2002). Flexible work arrangements are also important for individuals who have partners who also work (Robbins \& Judge, 2017) and arrangements such as long-distance work and flexible hours are often used to help individuals achieve a better work-life balance (Lim \& Teo, 2000; Rau \& Hyland, 2002; Spreitzer et al., 2017).

Flexible work arrangements can be seen in several forms: job sharing, telecommuting, and flextime (Allen et al., 2015). Employees widely use the application of flextime and telecommuting in flexible work settings in organizations. Flextime offers employees flexibility in determining their own work hours. Telecommuting attempts to change individuals' habit of being present in the office during business hours by 
enabling employees to complete work assignments outside the office. Flextime can be implemented by offering employees flexibility when they complete their work-for example, an employee may arrive at the office at 8 a.m. and go home at 4 p.m. (Thompson et al., 2015). When telecommuting is implemented, employees can complete work assignments from home (or another venue outside the office). They are still being supervised via computer networks and with no change to their job responsibilities (Golden \& Gajendran, 2019; Rau \& Hyland, 2002; Ryan \& Wessel, 2015).

As noted, the application of flexible work arrangements can help employees balance their work and outside-of-work activities (Rau \& Hyland, 2002; Spreitzer et al., 2017). Employees in dilemma situations tend to regard flexible work arrangements positively, seeing them as an effort to maximize their performance at work and reduce their sense of conflict (Golden \& Gajendran, 2019; Radcliffe \& Cassell, 2014). For example, employees often experience a family emergency (e.g. sick family members) so they need to go home early or not going to work for some periods of time. This situation may increase dilemma situation particularly if they need to finish their work at the same time. Flexible work arrangements can help to balance work and family responsibilities so that they can make decisions ethically. When an organization adopts flexible work arrangements, employees can direct their behavior toward ethical decision making and consider the consequences of their decisions to act morally.

Based on this, this study's research question is that two types of flexible work arrangements (flextime and telecommuting) influence ethical decision-making differently. These types of flexible work arrangements are distinguished because the application of telecommuting allows employees in an organization to do work from another place with the help of technology such as the internet and computers while employees who apply flextime allow employees to choose the time to start and end work based on the agreed time set by organization (Rau \& Hyland, 2002).

\section{Methods}

This study used an experimental design. A total of 185 employees participated in the study, all of whom worked either in government or in private companies. Participants were selected randomly from a group of volunteers who were willing to take part in the study. The online survey tool SurveyMonkey was used to assist in data collection and randomization. Attention check items (e.g., "I am the current President of Indonesia") were also included to eliminate any participants who were answering the survey carelessly and thereby to maintain the validity of the data (Evans \& Mathur, 2005; Kung et al., 2018). Those who completed the survey received as a reward an electronic voucher valued at IDR $10,000.00$.

Two vignettes or scenarios were used in the survey, with participants being divided into two groups: flextime and telecommuting (vignettes can be obtained upon request). After being given a randomly assigned scenario, participants were asked to read the scenario and then answer questions about ethical decision-making that related to the scenario. At the end of the survey, participants were asked to provide demographic information about their gender, marital status, employment, and income per month. 
The two scenarios each contained a moral dilemma situation to measure employees' tendencies toward ethical decision-making. The scenarios were designed based on telecommuting and flextime contexts to obtain a combination of responses. The telecommuting vignette related to personal matters at work, while the flextime vignette was about employee status abuse. Scenarios in the context of telecommuting were based on employee behavior to do personal works during office hours. The behavior can be said to be a dilemma because the behavior is contrary to the organization's rules. The use of computers and the internet facilitates personal works where the computer is connected to a confidential company database. Therefore, there was a breach of internet use by the employee. In the context of flextime, scenarios were based on employee behavior using her position to force her staff to commit fraud. She asked her assistant to submit her attendance even though she was not at the office anymore due to personal matters.

Each scenario was accompanied by seven questions to measure ethical decision-making: three short-response questions and four questions in which responses were given on a scale of one to five (strongly disagree to agree strongly). An example of a telecommuting item in the form of a short response question is "In your opinion, is Mira's conduct of personal affairs during office hours ..." with response options "acceptable" and "unacceptable". While examples of flextime items are questions with a scale response that was "In your opinion, the behavior of using office hours for personal matters is a problem ..." with response choices "very important" and "not important". An example of a flextime item in the form of a short response question was "In your opinion, does Amanda's behavior force his subordinates to commit fraud such as reporting attendance even if absent ..." with response options "acceptable" and "unacceptable". While examples of flextime items in the form of questions with scale responses are "In your opinion, coercive and intimidating behavior for the sake of personal interests is a problem ..." with response choices "very important" and "not important". The measurement had a minimum total score of six and a maximum total score of 23 , so that the higher a participant's total score, the higher their ethical decision-making, and the lower the total score, the lower their ethical decision-making.

Data analysis in this study employed the independent sample t-test using the SPSS software version 22.0). The t-test was used to determine differences in flexible work arrangements on ethical decision-making between the flextime and the telecommuting groups.

\section{Results}

Overall, 43.8 percent of participants in this study were male $(n=81)$ and 56.2 percent were female $(n=102)$. A total of 21.6 percent were employees in the government (state-owned) $(\mathrm{n}=40)$, while 78.4 percent worked as employees in private companies $(n=145)$. The results of statistical tests (using the independent sample t-test method) showed that the average value of the flextime group consisted of 83 participants $(\mathrm{M}=18.12 ; \mathrm{SD}=4.32)$, and the average value of the telecommuting group consisted of 102 participants $(\mathrm{M}=15.47$; SD = 4.20). Thus, there were differences in the mean scores of flexible work arrangements in the 
flextime and telecommuting groups. The t-test analysis also showed that the $t=4.207>t$-table $1.980(\mathrm{df}=183)$, it can be concluded that there are differences in the average flexible work arrangements in ethical decision making by comparing flextime and telecommuting groups so that the application of flexible work arrangements in the context of flextime and telecommuting will result in different ethical decision making.

Based on the results of the independent t-test sample, it is known that the significant value of Levene's test for equality of variances is $.308>.05$; therefore, it can be interpreted that the data variance between the flextime group and the telecommuting group is homogeneous (or the same) and that the significance value is $.00(\mathrm{p}<.05)-$ so $\mathrm{H} 0$ is rejected. Based on the data analysis, it can be concluded that there is a significant difference in mean between the two groups. It means that this study's hypothesis is acceptable-that is, there were differences in flexible work arrangements on ethical decisionmaking between flextime and telecommuting groups.

\section{Discussion}

Ethical decision-making in organizations is observed in employees' reactions when facing dilemma situations (Trevino, 1986). Flexible work arrangements may be a solution for individuals who want to balance their work and activities outside of work. When making decisions in a dilemma situation, the individual considers ethical decisions to act morally. Flexible work arrangements can both provide benefits for employees, enabling them to manage their time and work effectively, and influence their ethical decision making to act morally.
Employees can also manage their work schedules and complete work tasks without being present in the office (Rau \& Hyland, 2002; Ryan \& Wessel, 2015; Spreitzer et al., 2017). Therefore, they are still involved in their work while also being more responsible in managing their time between work and personal life.

Individuals making decisions regarding the regulation of flexible work hours must obtain support from the organization. It is because such decision-making relates to the application of individual morals. The presence of ethical or unethical behavior in an organization, which can cause profit or loss, is thus considered a consequence of individuals' influence (Trevino \& Youngblood, 1990).

According to Nelson and Quick (2013), the factors that influence ethical decision-making within the organization's scope consist of individual factors and organizational factors. One organizational factor that can act as a predictor of ethical decision-making is organization culture, especially when the culture is supportive or innovative (Cameron \& Quinn, 2001). Previous research stated that supportive and creative cultures can encourage individuals to apply values that represent organizational norms in their decision-making behaviors (Hartnell et al., 2011).

Within an organization, culture can play an important role in implementing policies and benefits for employees who want to balance their work and outside-of-work activities. Organizational culture can be defined as a value system that exists within an organization that can influence its members to exhibit the work practices and behaviors of productive employees (Choi \& Scott, 2008). Organizations with strong 
cultures are supportive and innovative (Sok et al., 2014). According to Hartnell et al. (2011), a supportive organizational culture emphasizes individual self-development and the internalization of moral values as a means of supporting ethical decision-making. An innovative organizational culture emphasizes individual performance results, with employees being encouraged to innovate and make ethical decisions (Mohanty et al., 2012).

Supportive and innovative organizational cultures include flexibility that supports individuals to achieve a work-life balance (Sok et al., 2014). In organizations with a supportive culture, colleagues and superiors will show support, and employees will be allowed to create a career without working long hours and arrange their work schedules (Linehan \& Walsh, 2000; Magnus \& Viswesvaran, 2006). Organizations with an innovative culture require their employees to possess a considerable degree of flexibility in regard to time demands (Sok et al., 2014). Implementing flexible work arrangements and support for the organizational culture can encourage the achievement of work-life balance. When the organization supports these conditions, employees will more effectively direct their behavior in the workplace toward enhanced ethical decision-making and have a better consideration of the consequences of their decisions.

\section{Conclusion}

This study's research question is related to whether flextime and telecommuting employees approach ethical decision-making differently. The question research has been answered by results showing that the value of $t$ is greater than the $t$ table $(4,207>1,980)$. Therefore, there were differences in flexible work arrangements on ethical decision making between flextime and telecommuting groups.

This study has limitations, but it presents possible directions for future studies. While this study involved relatively few participants, it is hoped that future studies will utilize larger cohorts to enrich the data produced. Subsequent studies could also add selected organizational factors to measure the influence of flexible work arrangements in the workplace. Besides, postonly experimental studies may intervene in participants' perceptions of the scenarios. It is better than those participants who are assessed pre- and post-giving up the scenarios to make sure their perception of the scenario influences their ethical decision-making.[]

\section{References}

Allen, T. D., Golden, T. D., \& Shockley, K. M. (2015). How effective is telecommuting? Assessing the status of our scientific findings. Psychological Science in the Public Interest, 16(2), 40-68. https://doi.org/10.1177/1529100615593273

Bazerman, M. H., \& Sezer, O. (2016). Bounded awareness: Implications for ethical decision making. Organizational Behavior and Human Decision Processes, 136, 95-105. https://doi.org/10.1016/j.obhdp.2015.11.004

Cameron, K. S., \& Quinn, R. E. (2001). Diagnosing and changing organizational culture: Based on the competing values framework. Jossey-Bass. 
Carlson, D. S., Kacmar, K. M., \& Wadsworth, L. L. (2009). The impact of moral intensity dimensions on ethical decision-making: Assessing the relevance of orientation. Journal of Managerial Issues, 21(4), 15-30.

Choi, Y. S., \& Scott, D. K. (2008). Assessing organisational culture using the competing values framework within American Triple-A baseball. International Journal of Sport Management and Marketing, 4(1), 33-48. https://doi.org/10.1504/IJSMM.2008.017657

Evans, J. R., \& Mathur, A. (2005). The value of online surveys. Internet Research, 15(2), 195-219. https://doi.org/10.1108/10662240510590360

Golden, T. D., \& Gajendran, R. S. (2019). Unpacking the role of a telecommuter's job in their performance: Examining job complexity, problem solving, interdependence, and social support. Journal of Business and Psychology, 34(1), 55-69. https://doi.org/10.1007/s10869-018-9530-4

Hartnell, C. A., Ou, A. Y., \& Kinicki, A. (2011). Organizational culture and organizational effectiveness: A meta-analytic investigation of the competing values framework's theoretical suppositions. Journal of Applied Psychology, 96(4), 677-694. https://doi.org/10.1037/a0021987

Jones, T. M. (1991). Ethical decision making by individuals in organizations: An issue-contingent model. Academy of Management Review, 366-395. https://doi.org/10.5465/amr.1991.4278958

Kung, F. Y. H., Kwok, N., \& Brown, D. J. (2018). Are attention check questions a threat to scale validity? Applied Psychology, 67(2), 264-283. https://doi.org/10.1111/apps.12108

Lim, V. K. G., \& Teo, T. S. H. (2000). To work or not to work at home: An empirical investigation of factors affecting attitudes towards teleworking. Journal of Managerial Psychology, 15(6), 560-586. https://doi.org/10.1108/02683940010373392

Lincoln, S. H., \& Holmes, E. K. (2010). The psychology of making ethical decisions: What affects the decision? Psychological Services, 7(2), 57-64. https://doi.org/10.1037/a0018710

Linehan, M., \& Walsh, J. S. (2000). Work-family conflict and the senior female international manager. British Journal of Management, 11(s1), S49-S58. https://doi.org/10.1111/1467-8551.11.s1.5

Magnus, J. R. M., \& Viswesvaran, C. (2006). How family-friendly work environments affect work/family conflict: A meta-analytic examination. Journal of Labor Research, 27(4), 555-574. https://doi.org/10.1007/s12122-006-1020-1

Mohanty, A., Dash, M., Pattnaik, S., Das, J. R., \& Misra, S. K. (2012). Study of organization culture and leadership behaviour in small and medium sized enterprises. European Journal of Scientific Research, 68(2), 258-267.

Musbah, A., Cowton, C. J., \& Tyfa, D. (2016). The role of individual variables, organizational variables and moral intensity dimensions in Libyan management accountants' ethical decision making. Journal of Business Ethics, 134(3), 335-358. https://doi.org/10.1007/s10551-014-2421-3

Nelson, D. L., \& Quick, J. C. (2013). Organizational behavior: Science, the real world, and you. Boston: Cengage Learning.

Pedersen, V. B., \& Lewis, S. (2012). Flexible friends? Flexible working time arrangements, blurred worklife boundaries and friendship. Work, Employment and Society, 26(3), 464-480. https://doi.org/10.1177/0950017012438571

Radcliffe, L. S., \& Cassell, C. (2014). Resolving couples' work-family conflicts: The complexity of decision making and the introduction of a new framework. Human Relations, 67(7), 793-819. https://doi.org/10.1177/0018726713506022 
Rau, B. L., \& Hyland, M. A. M. (2002). Role conflict and flexible work arrangements: The effects on applicant attraction. Personnel Psychology, 55(1), 111-136. https://doi.org/10.1111/j.17446570.2002.tb00105.x

Rest, J. R., \& Barnett, R. (1986). Moral development: Advances in research and theory. Praeger.

Robbins, S. P., \& Judge, T. A. (2017). Organizational behavior (17th ed.). Pearson.

Ryan, A. M., \& Wessel, J. L. (2015). Implications of a changing workforce and workplace for justice perceptions and expectations. Human Resource Management Review, 25(2), 162-175. https://doi.org/10.1016/j.hrmr.2015.01.001

Sok, J., Blomme, R., \& Tromp, D. (2014). Positive and negative spillover from work to home: The role of organizational culture and supportive arrangements. British Journal of Management, 25(3), 456-472. https://doi.org/10.1111/1467-8551.12058

Sparks, J. R., \& Pan, Y. (2010). Ethical judgments in business ethics research: Definition, and research agenda. Journal of Business Ethics, 91(3), 405-418. https://doi.org/10.1007/s10551-0090092-2

Spreitzer, G. M., Cameron, L., \& Garrett, L. (2017). Alternative work arrangements: Two images of the new world of work. Annual Review of Organizational Psychology and Organizational Behavior, 4(1), 473-499. https://doi.org/10.1146/annurev-orgpsych-032516-113332

Thompson, R. J., Payne, S. C., \& Taylor, A. B. (2015). Applicant attraction to flexible work arrangements: Separating the influence of flextime and flexplace. Journal of Occupational and Organizational Psychology, 88(4), 726-749. https://doi.org/10.1111/joop.12095

Trevino, Linda K., \& Youngblood, S. A. (1990). Bad apples in bad barrels: A causal analysis of ethical decision-making behavior. Journal of Applied Psychology, 75(4), 378-385. https://doi.org/10.1037/0021-9010.75.4.378

Trevino, Linda Klebe. (1986). Ethical decision making in organizations: A person-situation interactionist model. Academy of Management Review, 11(3), 601-617. https://doi.org/10.5465/amr.1986.4306235

Wisesa, A. (2011). Integritas moral dalam konteks pengambilan keputusan etis. Jurnal Manajemen Teknologi, 10(1), 82-92. 
This page has been intentionally left blank. 